\title{
The Natural Agonist of Estrogen Receptor $\beta$ Silibinin Plays an Immunosuppressive Role Representing a Potential Therapeutic Tool in Rheumatoid Arthritis
}

\section{OPEN ACCESS}

Edited by:

Carlo Selmi,

Università degli Studi di Milano, Italy

Reviewed by:

Juan Pablo Mackern-Oberti, Consejo Nacional de Investigaciones Cientificas y Técnicas (CONICET),

Argentina

Patrick Leung,

University of California, Davis, United States

${ }^{*}$ Correspondence: Elena Ortona elena.ortona@iss.it

tThese authors have contributed equally to this work.

Specialty section: This article was submitted to Cytokines and Soluble Mediators in Immunity, a section of the journal Frontiers in Immunology

Received: 29 March 2018 Accepted: 01 August 2018 Published: 17 August 2018

Citation:

Dupuis ML, Conti F, Maselli A, Pagano MT, Ruggieri A, Anticoli S, Fragale A, Gabriele L, Gagliardi MC, Sanchez M, Ceccarelli F,

Alessandri C, Valesini G, Ortona E and Pierdominici $M$ (2018) The

Natural Agonist of Estrogen

Receptor $\beta$ Silibinin Plays an Immunosuppressive Role Representing a Potential Therapeutic

Tool in Rheumatoid Arthritis.

Front. Immunol. 9:1903. doi: 10.3389/fimmu.2018.01903

\author{
Maria Luisa Dupuis ${ }^{1 \dagger}$, Fabrizio Conti2t, Angela Maselli', Maria Teresa Pagano', \\ Anna Ruggieri', Simona Anticoli', Alessandra Fragale ${ }^{3}$, Lucia Gabriele ${ }^{3}$, \\ Maria Cristina Gagliardi', Massimo Sanchez ${ }^{4}$, Fulvia Ceccarelli², Cristiano Alessandri², \\ Guido Valesini ${ }^{2}$, Elena Ortona ${ }^{1 *}$ and Marina Pierdominici'
}

${ }^{1}$ Center for Gender Specific Medicine, Istituto Superiore di Sanità, Rome, Italy, ${ }^{2}$ Rheumatology Unit, Department of Internal Medicine and Medical Specialties, Sapienza University of Rome, Rome, Italy, ${ }^{3}$ Department of Oncology and Molecular Medicine, Istituto Superiore di Sanità, Rome, Italy, ${ }^{4}$ Core Facilities, Istituto Superiore di Sanità, Rome, Italy

Estrogens, in particular $17 \beta$-estradiol (E2), have a strong influence on the immune system and also affect pathological conditions such as autoimmune diseases. The biological effects of E2 are mediated by two intracellular receptors, i.e., estrogen receptor (ER) $\alpha$ and ER $\beta$, which function as ligand-activated nuclear transcription factors producing genomic effects. Immune cells express both $E R \alpha$ and $E R \beta$ that play a complex role in modulating inflammation. Phytoestrogens display estrogen-like effects. Among them, silibinin, the major active constituent of silymarin extracted by the milk thistle (Silybum marianum), has been suggested to have an ER $\beta$ selective binding. Silibinin is known to have anti-inflammatory, hepatoprotective, and anticarcinogenic effects; however, the role of silibinin in modulating human immune responses and its impact on autoimmunity remains unclear. Aim of this study was to dissect the ability of the ER $\beta$ natural ligand silibinin to modulate $T$ cell immunity, taking into account possible differences between females and males, and to define its possible role as therapeutic tool in immune-mediated diseases. To this purpose, female and age-matched male healthy subjects and patients with active rheumatoid arthritis $(R A)$ were recruited. We evaluated the ability of silibinin to modulate ER $\beta$ expression in T lymphocytes and its effects on T cell functions (i.e., apoptosis, proliferation, and cytokine production). We also analyzed whether silibinin was able to modulate the expression of microRNA-155 (miR-155), which strongly contributes to the pathogenesis of RA driving aberrant activation of the immune system. We demonstrated that silibinin upregulated ER $\beta$ expression, induced apoptosis, inhibited proliferation, and reduced expression of the pro-inflammatory cytokines IL-17 and TNF- $\alpha$, through ER $\beta$ binding, in T Iymphocytes from female and male healthy donors. We obtained similar results in T lymphocytes from patients with active RA in term of apoptosis, proliferation, and cytokine production. In addition, we found that silibinin acted as an epigenetic modifier, down-modulating the expression of miR-155. In conclusion, our data demonstrated 
an immunosuppressive role of silibinin, supporting its application in the treatment of autoimmune diseases as drug, but also as dietary nutritional supplement, opening new perspective in the field of autoimmune disease management.

\section{Keywords: estrogen receptor $\beta$, silibinin, $\mathrm{T}$ lymphocytes, immunity, sex, rheumatoid arthritis}

\section{INTRODUCTION}

It is well known that estrogen (17 $\beta$-estradiol-E2) influences different aspects of the immune system function and potentially affects the risk, activity, and progression of autoimmune diseases (1-4). In particular, E2 is able to modulate different aspects of immune responses, e.g., lymphocyte proliferation and apoptosis, cytokine, or antibody production (5-8). The immunomodulatory effects exerted by E2 are, at least partially, responsible for the existing differences between female and male immune systems, with females mounting stronger humoral and cellular immune responses than males (6). As a consequence, females are generally more resistant to infection but more susceptible to autoimmune diseases that are typically dominant in women in comparison to men $(4,9,10)$. The most important factors responsible for this sex bias are sex hormones, genetic and epigenetic factors, as well as sociological differences between genders. Notably autoimmune diseases differ between males and females not only for their incidence but also for clinical outcome and response to therapy.

$17 \beta$-estradiol effects are mediated by two intracellular estrogen receptors (ER), i.e., $\mathrm{ER} \alpha$ and $\mathrm{ER} \beta$, which act as ligand-activated nuclear transcription factors generating genomic effects $(8,11)$. Our and other groups have demonstrated that immune cells express both $\operatorname{ER} \alpha$ and $\operatorname{ER} \beta$ (12-15) which have a complex role in modulating inflammation, thus representing potential therapeutic targets in autoimmune diseases (16-20). In particular, the low intracellular expression level of ER $\beta$ has been demonstrated to be associated with high disease activity in chronic inflammatory diseases such as systemic lupus erythematosus (21) and inflammatory bowel diseases (22). The downregulation of this receptor has been found to be dependent by a pro-inflammatory microenvironment (22). Accordingly, ER $\beta$ agonist ligands have been suggested to dampen inflammation in animal models of autoimmune diseases $(17,23)$.

Interestingly, some phytoestrogens, naturally occurring plant compounds, display ER $\beta$ selective binding with estrogen-like effects. Among them, silibinin (24), the major active constituent of silymarin extracted by the milk thistle (Silybum marianum), has been suggested by in silico studies to have an $\operatorname{ER} \beta$ selective binding acting as agonist of this ER (25). Silibinin has been demonstrated to have anti-inflammatory, hepatoprotective, and

\footnotetext{
Abbreviations: APC, allophycocyanin; AV, annexin V; DAS28, disease activity score 28; E2, 17 $\beta$-estradiol; ER, estrogen receptor; FITC, fluorescein isothiocyanate; GAPDH, glyceraldehyde 3-phosphate dehydrogenase; mAb, monoclonal antibody; miR-155, microRNA-155; PBMC, peripheral blood mononuclear cell; PE, phycoerythrin; PHTPP, 4-[2-phenyl-5,7-bis(trifluoromethyl)pyrazolo[1,5-a] pyrimidin-3-yl]phenol; PI, propidium iodide; PMA, phorbol myristate acetate; RA, rheumatoid arthritis; qRT-PCR, quantitative real-time PCR; siRNA, small interfering RNA; SSNC, silencer select negative control.
}

anticarcinogenic properties interfering with multiple biochemical pathways (26); however, the role of silibinin in modulating human immune responses and its impact on autoimmunity remains unclear.

Hence, the aim of this study was to dissect the ability of the $\operatorname{ER} \beta$ natural ligand silibinin to modulate $\mathrm{T}$ cell immunity, taking into account possible differences between females and males, and to define its possible role as a therapeutic tool in immune-mediated diseases. To this purpose, we first evaluated the ability of silibinin to modulate ER $\beta$ expression in T lymphocytes from female and age-matched male healthy subjects and its effects on $\mathrm{T}$ cell functions (i.e., apoptosis, proliferation, and cytokine production). Then we analyzed the effects played by silibinin on T lymphocytes from patients affected by rheumatoid arthritis (RA), a chronic autoimmune inflammatory disease, characterized by synovial inflammation and by cartilage and bone destruction (27), in which T lymphocytes play a key pathogenetic role (27). We also evaluated whether silibinin could modulate the expression of microRNA-155 (miR-155) which is involved in the modulation of T lymphocyte immunity (28) and strongly contributes to the pathogenesis of RA driving aberrant activation of the immune system (29-31).

\section{MATERIALS AND METHODS}

\section{Study Population}

Forty-four healthy subjects (23 postmenopausal females and 21 age-matched males, age range $55-75$ years) as well as 10 postmenopausal female patients and 4 age-matched male patients with active RA, who had an inadequate response to drugs, followed at the Rheumatology outpatient Clinic (Arthritis Center, Policlinico Umberto I, Sapienza University of Rome, Italy), were included in the study. All RA patients fulfilled the 2010 American College of Rheumatology/European League against Rheumatism (ACR/EULAR) classification criteria (32). Exclusion criteria were pregnancy, treatment with any kind of hormones. Clinical evaluation included the count of swollen and tender joints, patient and physician global disease assessment by VAS (0-100 mm). Disease activity was measured by Disease Activity Score 28 (DAS28) and clinical response was evaluated according to EULAR response criteria (33). The following laboratory tests were performed: complete blood count, erythrocyte sedimentation rate, C-reactive protein, antinuclear antibodies, rheumatoid factor, and anticyclic citrullinated peptide antibodies. Demographic and clinical features of RA patients are shown in Table 1 .

This study was carried out in accordance with the recommendations of the Declaration of Helsinki. Written informed consent was obtained from all subjects, and the ethics committee of the Policlinico Umberto I (Rome, Italy) approved the study. 
TABLE 1 | Demographic and clinical features of rheumatoid arthritis patients (females, $N=10$; males, $N=4$ ).

\begin{tabular}{lcc}
\hline Patients features & Females & Males \\
\hline Median age (years), IQR & $60(18.5)$ & $61.5(9.0)$ \\
Median disease duration (years), IQR & $17(15.5)$ & $9.5(5.5)$ \\
Median DAS28, IQR & $5.5(1.3)$ & $5.9(1)$ \\
PDN, N/\% & $1 / 88.8$ & $1 / 25$ \\
sDMARDs treatment, N/\% & $5 / 62.5$ & $4 / 100$ \\
bDMARDs drugs, N/\% & $4 / 44.4$ & 0
\end{tabular}

IQR, InterQuartile range; PDN, prednisone; DAS28, Disease Activity Score 28; sDMARDs, synthetic disease-modifying antirheumatic drugs; bDMARDs, biologic disease-modifying antirheumatic drugs; $N$, number.

\section{Isolation of Peripheral Blood Mononuclear Cells (PBMCs) and Cell Culture Conditions}

Peripheral blood mononuclear cells were isolated by FicollHypaque density-gradient centrifugation and cultured in RPMI-1640 medium without phenol red (Gibco BRL, Grand Island, NY, USA) supplemented with $10 \%$ charcoal-stripped fetal bovine serum (Hyclone Laboratories, South Logan, UT, USA), $2 \mathrm{mM}$ glutamine (Sigma, St. Louis, MO, USA), and $50 \mu \mathrm{g} / \mathrm{ml}$ gentamycin (Sigma). Silibinin (Sigma) was dissolved in dimethyl sulfoxide and diluted in RPMI 1640. Preliminary dose response and time course experiments showed that silibinin should be used at a dose of $50 \mu \mathrm{M}$ and at 24-72 $\mathrm{h}$ of culture (depending on the studied parameters) to obtain the highest detectable changes in the absence of toxic effects. For lymphocyte activation, PBMCs or sorted $\mathrm{CD}^{+}{ }^{+} \mathrm{CD} 45 \mathrm{RA}^{-} \mathrm{CCR} 6^{+} \mathrm{CXCR}^{-}$(see below for sorting) were cultured in the presence of plate-bound anti-CD3 monoclonal antibody (mAb, clone UCHT1, R\&D Systems, Minneapolis, MN, USA) at $4 \mu \mathrm{g} / \mathrm{ml}$ for $72 \mathrm{~h}$ and treated with silibinin for the last $48 \mathrm{~h}$ of culture. In separate experiments, cells were pretreated with $100 \mathrm{nM}$ 4-[2-phenyl-5,7-bis(trifluoromethyl)pyrazolo[1,5a]pyrimidin-3-yl]phenol (PHTPP) ER $\beta$ antagonist (Tocris Cookson, Ellisville, MO, USA) for $1 \mathrm{~h}$ before adding silibinin.

For cytokine production, untreated or treated PBMCs were stimulated as follows: (i) for IFN- $\gamma$, TNF- $\alpha$, IL-2, and IL-4 analysis, $25 \mathrm{ng} / \mathrm{ml}$ phorbol myristate acetate (PMA, Sigma) and $1 \mu \mathrm{g} / \mathrm{ml}$ ionomycin (Sigma) for the last $16 \mathrm{~h}$ of culture; (ii) for IL-17 analysis, $50 \mathrm{ng} / \mathrm{ml}$ PMA (Sigma) and $1 \mu \mathrm{g} / \mathrm{ml}$ ionomycin (Sigma) for the last $4 \mathrm{~h}$ of culture; and (iii) for IL-10, $2.5 \mu \mathrm{g} / \mathrm{ml}$ phytohemagglutinin (Sigma) for the last $16 \mathrm{~h}$ of culture. To inhibit cytokine secretion, $10 \mu \mathrm{g} / \mathrm{ml}$ brefeldin A (Sigma) was added to each condition at the beginning of stimulation.

\section{Flow Cytometry}

Cell surface phenotyping was performed by flow cytometry as previously described (13). Allophycocyanin (APC)-conjugated anti-CD3, APC- or phycoerythrin (PE)-conjugated anti-CD4, peridinin chlorophyll protein-conjugated anti-CD8 mAbs (all from BD Biosciences, San Jose, CA, USA) were used. Equal amount of mouse IgG isotype control was run in parallel. Analysis of cytokine production at the single cell level was performed as previously described with minor changes (34). Briefly, treated cells (see above for details) were either fixed with $4 \%$ paraformaldehyde and permeabilized with FACS permeabilizing solution
(BD Biosciences) for IFN- $\gamma$, TNF- $\alpha$, IL-2, IL-4, and IL-10 detection or fixed and permeabilized with intracellular fixation and permeabilization buffer (eBioscience, San Diego, CA, USA) for IL-17 detection. The following cytokine-specific mAbs were used: fluorescein isothiocyanate (FITC)-labeled anti-IFN- $\gamma$, FITC-labeled anti-IL-2, PE-labeled anti-TNF- $\alpha$, PE-labeled anti-IL-4, PE-labeled anti-IL-10 (all from BD Biosciences), and FITC-labeled anti-IL-17A (eBioscience). Appropriate isotypic negative controls were run in parallel. Apoptosis was quantified using FITC- or PE-conjugated annexin V (AV) and propidium iodide (PI) detection kit (Marine Biological Laboratory, Woods Hole, MA, USA) according to the manufacturer's protocol. Proliferation was evaluated by measuring Ki-67 nuclear antigen expression using FITC-labeled anti-human Ki-67 mAb according to the manufacturer's protocol (BD Biosciences). For ER $\beta$ intracellular staining of sorted $\mathrm{CD} 4^{+} \mathrm{CD} 45 \mathrm{RA}^{-} \mathrm{CCR}^{+}{ }^{+} \mathrm{CXCR}^{-}{ }^{-}$Th17 lymphocytes, cells were fixed and permeabilized as described above, and stained with the anti-ER $\beta \mathrm{mAb}$ (clone CWK-F12 from DSHB, Iowa City, IA, USA). Equal amount of mouse IgG isotype control was run in parallel. The primary antibody was visualized by FITC-conjugated $\mathrm{F}\left(\mathrm{ab}^{\prime}\right) 2$ fragment secondary antibody (Abcam, Cambridge, UK).

To determine the frequency of $\mathrm{T}$ cell subsets, total lymphocytes were first gated by forward and side scatter and then additionally gated for CD3 and CD4 or CD3 and CD8 molecule expression. Acquisition was performed on a FACSCalibur flow cytometer (BD Biosciences) and at least 50,000 events per sample were run. Data were analyzed using the Cell Quest Pro software (BD Biosciences).

\section{MACS and FACS Cell Sorting}

For Western blot and quantitative real-time PCR (qRT-PCR) analyses, untouched T cells were separated using the Pan T Cell isolation Kit II (Miltenyi Biotec, Bergisch-Gladbach, Germany). The purity of recovered cells, assessed by flow cytometer, was $\geq 97 \%$.

For apoptosis and ER $\beta$ analyses of Th17 cells (i.e., $\left.\mathrm{CD}^{+}{ }^{+} \mathrm{CD} 45 \mathrm{RA}^{-} \mathrm{CCR}^{+}{ }^{+} \mathrm{CXCR} 3^{-}\right), \mathrm{CD}^{+}{ }^{+} \mathrm{T}$ cells were separated from PBMCby positive selection using CD4 MicroBeads (Miltenyi Biotec), with a purity $\geq 97 \%$, as determined by flow cytometer. Then, $\mathrm{CD}^{+}{ }^{+} \mathrm{CD} 45 \mathrm{RA}^{-} \mathrm{CCR} 6^{+} \mathrm{CXCR} 3^{-} \mathrm{T}$ cell subset was sorted by FACS (BD FACSAria; BD Biosciences) upon staining with the following mixture of mAb: CD4 PE/Cy7 (BD Biosciences), CD45RA FITC (BD Biosciences), CCR6 PE (Miltenyi Biotec), and CXCR3 APC (BD Biosciences). Sorted T cell subset was on average $>95 \%$ pure as determined by postsorting flow cytometry analysis.

\section{SDS-PAGE and Western Blot}

SDS-PAGE and Western blot were performed as previously described (13). Briefly, cells were lysed in RIPA buffer [100 mM tris(hydroxymethyl)aminomethane (Tris)- $\mathrm{HCl} \mathrm{pH} \mathrm{8,} 150 \mathrm{mM}$ $\mathrm{NaCl}, 1 \%$ Triton X-100, $1 \mathrm{mM} \mathrm{MgCl}_{2}$ ] in the presence of a complete protease-inhibitor mixture. Protein content was determined by the Bradford assay (Bio-Rad Laboratories, Richmond, CA, USA). Cell lysates $(30 \mu \mathrm{g} / \mathrm{ml})$ were loaded onto SDS-PAGE and, after electrophoresis, proteins were transferred onto nitrocellulose 
membrane (GE Healthcare, Pittsburgh, PA, USA) by means of a Trans-Blot transfer cell (Bio-Rad Laboratories). The membranes were then blocked in 5\% nonfat milk and incubated with the appropriate antibodies in Tris-buffered saline containing $0.1 \%$ Tween 20 and 5\% nonfat milk. Anti-ER $\beta$ mAb (clone CWK-F12 from DSHB) was used as primary Ab. Peroxidase-conjugated goat anti-mouse IgG was used as secondary Ab (Bio-Rad Laboratories) and the reactions were developed using the SuperSignal West Pico Chemiluminescent Substrate (Pierce, Rockford, IL, USA). To ensure the presence of equal amounts of protein, the membranes were reprobed with a rabbit anti-human glyceraldehyde 3-phosphate dehydrogenase Ab (Sigma). Quantification of protein expression was performed by densitometry analysis of the autoradiograms (GS-700 Imaging Densitometer, Bio-Rad Laboratories).

\section{qRT-PCR Analysis of miR-155 Expression Level}

Total RNA, including short RNA, was isolated from T lymphocytes of female RA patients, treated and untreated with silibinin for $48 \mathrm{~h}$, using the Total RNA Purification Plus Kit (Norgen Biotek Corp., Thorold, ON, Canada), according to the manufacturer's instructions. RNA samples, after quantity evaluation using a NanoDrop ND-1000 spectrophotometer, were used for qRT-PCR analysis. miR-155 and RNU6B, as normalizator, expression levels were quantitated using specific inventoried TaqMan MicroRNA Assays (Thermo Fisher Scientific, Waltham, MA USA), according to the manufacturer's instructions, and all samples were run in triplicate. Briefly, 15 ng of each RNA sample were reverse transcribed by the Taq-Man ${ }^{\circledR}$ MicroRNA Reverse Transcription (RT) Kit (Thermo Fisher Scientific) using individual miR-specific RT primers, and $1.3 \mu \mathrm{l}$ of RT product were analyzed by qRT-PCR on the ABI7000 Real-Time PCR System (Applied Biosystem, Foster City, CA, USA). The relative expression level of miR-155 was determined by the $2-\Delta \Delta \mathrm{Ct}$ method, after normalization to the RNU6B Ct. $1.5 \mathrm{miR}$ fold changes between RA patients treated or untreated with silibinin were considered significant.

\section{qRT-PCR Analysis of ER $\beta$ mRNA Expression Level}

Total RNA was extracted from cells using the RNeasy Mini kit (Qiagen, Milan, Italy). RNA was DNase-I digested (Roche) and reverse transcribed as previously described (35). Quantitative PCR was performed in duplicate by the real-time fluorescence detection method with the fluorescent DNA binding dye SYBR green (Power SYBR Green PCR master kit; Applied Biosystems) by using an ABI PRISM 7900 (Applied Biosystems). The relative expression levels were calculated by the comparative cycle threshold $(\Delta \Delta \mathrm{Ct})$ method and were normalized by hypoxanthine-guanine phosphoribosyl transferase expression. Homo sapiens estrogen receptor 2 (ESR2, ER $\beta 1$ ) primers used for RT-PCR were designed by using the Primer3Plus software, crossing exon-intron junctions and checking for secondary structures; sequences are 5'-GCTCCTGTCCCACGTCAG-3', $5^{\prime}$-CACATAATCCCATCCCAAGC-3'.

\section{ER $\beta$ Silencing by Small Interfering RNA (siRNA)}

The silencing of ER $\beta$ was performed with the following Silencer Select siRNA for ESR2, sense, AGUGUACAAUCGAUAAAA ATT, antisense, UUUUUAUCGAUUGUACACUGA (Ambion, Milan, Italy). Silencer select negative control siRNA (SSNC, Ambion) was also used as negative control. For transfection of human T lymphocyte, the Amaxa Human T cell Nucleofector ${ }^{\circledR}$ kit was used (Lonza, Walkersville, MD, USA) according to the manufacturer's protocol. In brief, $6 \times 10^{6}$ cells per condition were resuspended in $100 \mu \mathrm{l}$ of the Nucleofactor kit solution, combined with $300 \mathrm{nM}$ of the indicated siRNA or pmaxGFP vector $(2 \mu \mathrm{g})$, and electroporated using the U-014 program of the Nucleofector (Amaxa Biosystems, Köln, Germany). Transfection efficiency was monitored in all samples by FACS analysis of GFP fluorescence and was about 50\%. Cell apoptosis, measured by AV/PI detection kit was $<20 \%$ (data not shown). After $6 \mathrm{~h}$, siRNA-transfected PBMCs were treated with silibinin (Sigma) for $48 \mathrm{~h}$ and analyzed for IL-17 and TNF- $\alpha$ expression after stimulation with PMA and ionomycin (both from Sigma) in the presence of brefeldin A (Sigma). See above for methodological details.

\section{Statistical Analysis}

Statistical analysis was performed by the Mann-Whitney $U$ test using GraphPad Prism, version 7.0 software (GraphPad Software, San Diego, CA, USA). A $P$ value $<0.05$ was considered statistically significant.

\section{RESULTS}

\section{The Natural ER $\beta$ Agonist Silibinin Modulates ER $\beta$ Expression in Peripheral Blood T Lymphocytes From Female and Male Healthy Subjects}

As stated above, we and other groups previously demonstrated that immune cells have detectable levels of intracellular ER $\beta$ $(12-14)$. As literature data indicate for phytoestrogens the ability to upregulate $\operatorname{ER} \beta$ in different cell types $(36,37)$, we first evaluated if this effect could be also evident in silibinin-treated $\mathrm{T}$ lymphocytes, taking into account possible differences between females and males. To this aim, both mRNA and protein expression level of ER $\beta$ was determined by qRT-PCR and Western blot analysis in peripheral T lymphocytes (Figures 1A-C) from healthy subjects after $16 \mathrm{~h}$ treatment with silibinin. A significant increase of $\operatorname{ER} \beta$ mRNA expression level was detectable after treatment with silibinin in T cells (treated versus untreated cells, $P=0.01$ and $P=0.0274$, in females and males, respectively, Figure 1A). Hence, we analyzed by Western blot the protein expression level of ER $\beta$ in T lymphocytes and we found significantly higher levels of ER $\beta$ in silibinin-treated cells when compared with untreated cells (treated versus untreated cells, $P<0.0001$ in both females and males, Figures 1B,C). T lymphocytes from female and male subjects showed comparable susceptibility to silibinin treatment. 
A

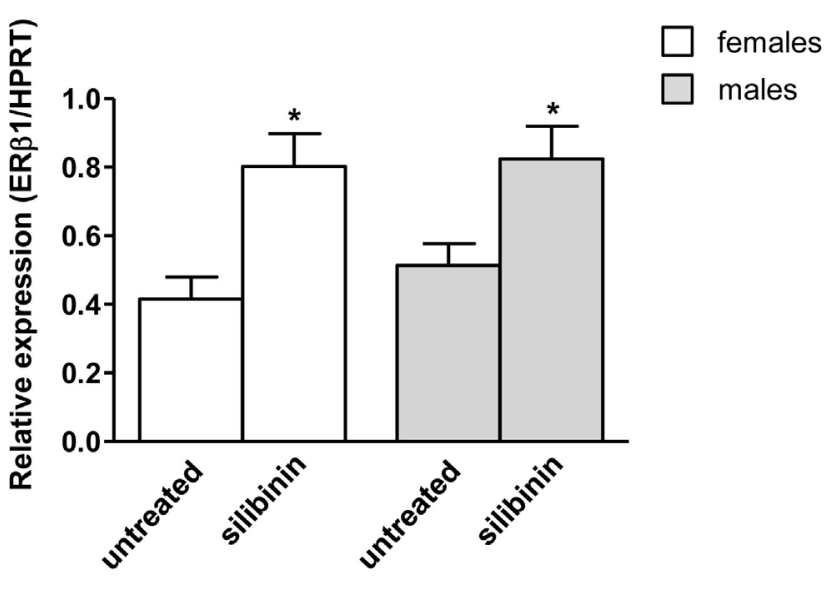

B

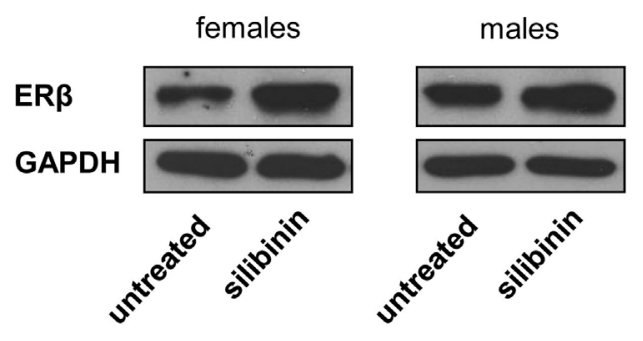

C

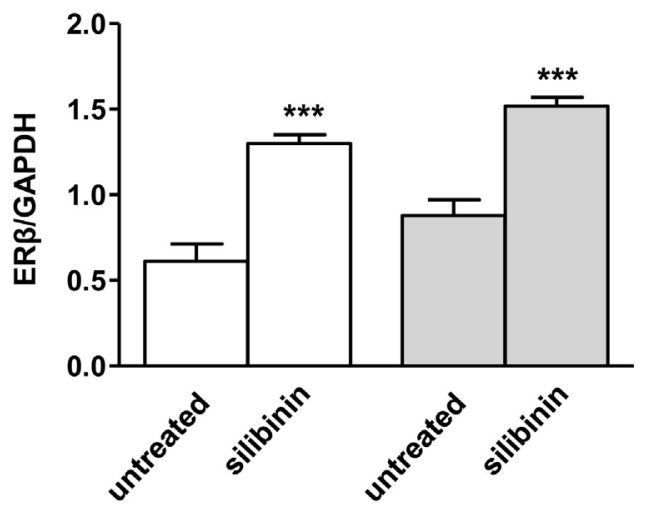

FIGURE 1 | Silibinin increased the expression of estrogen receptor (ER) $\beta$ in peripheral blood T lymphocytes from female and male healthy subjects. (A) ER $\beta 1$ mRNA levels were evaluated by quantitative real-time PCR after $24 \mathrm{~h}$ silibinin treatment. Data are expressed as ratios of the expression of ER $\beta 1$ and hypoxanthine-guanine phosphoribosyl transferase (HPRT) gene. Results are shown as mean \pm SD from 10 randomly selected female and male healthy subjects. (B,C) ER $\beta$ protein levels were also evaluated by Western blot analysis of T-cell lysates after $24 \mathrm{~h}$ silibinin treatment. Blots shown are representative of experiments performed in T cells from 10 randomly selected female and male healthy subjects (B). Densitometry analysis of ER $\beta$ levels relative to glyceraldehyde 3-phosphate dehydrogenase (GAPDH) is also shown. Values are expressed as mean \pm SD (C). ${ }^{*} P<0.05,{ }^{* \star *} P<0.001$ versus untreated cells.

\section{Silibinin-Dependent Effects on Cell Apoptosis, Cell Proliferation, and Cytokine Production in Peripheral Blood T Lymphocytes From Female and Male Healthy Subjects}

As a second step, we evaluated the ability of silibinin to impact $\mathrm{T}$ lymphocyte homeostasis in term of cell apoptosis, proliferation, and cytokine production. Silibinin was able to induce a significant increase in resting $\mathrm{T}$ lymphocyte apoptosis (treated versus untreated cells, $P=0.0002$ and $P=0.0074$, in females and males, respectively, Figures 2A,B). Similarly, activated $\mathrm{T}$ cells treated with silibinin showed a significant increase of apoptotic levels (treated versus untreated cells, $P=0.0029$ and $P=0.0013$, in females and males, respectively, Figures 2C,D).
In parallel, a significant reduction of proliferation of activated T lymphocytes, measured by the analysis of nuclear antigen Ki-67 expression, was observed after treatment with silibinin (treated versus untreated cells, $P=0.0024$ and $P=0.0081$, in females and males, respectively, Figures 2E,F).

A panel of pro-inflammatory (IFN $\gamma$, TNF- $\alpha$, IL-2, and IL-17) and anti-inflammatory (IL-4 and IL-10) cytokines was also studied. Notably, silibinin significantly reduced the intracellular expression level of the pro-inflammatory cytokines IL-17 and TNF- $\alpha$ in $\mathrm{CD}^{+} \mathrm{T}$ lymphocytes (for IL-17, treated versus untreated cells, $P=0.0078$ and $P=0.0077$, in females and males, respectively, Figures 3A,B; for TNF- $\alpha$, treated versus untreated cells, $P=0.0028$ and $P=0.0272$, in females and males, respectively, Figures $4 \mathrm{~A}, \mathrm{~B})$. No changes were induced by silibinin in the percentage of $\mathrm{CD}^{+} / \mathrm{TNF}-\alpha^{+}, \mathrm{CD}^{+} /$and $\mathrm{CD} 8^{+} / \mathrm{IL}-2^{+}, \mathrm{IFN} \gamma^{+}$, IL- $4^{+}$, and IL- $10^{+}$T lymphocytes (Table 2 ). In order to clarify the 

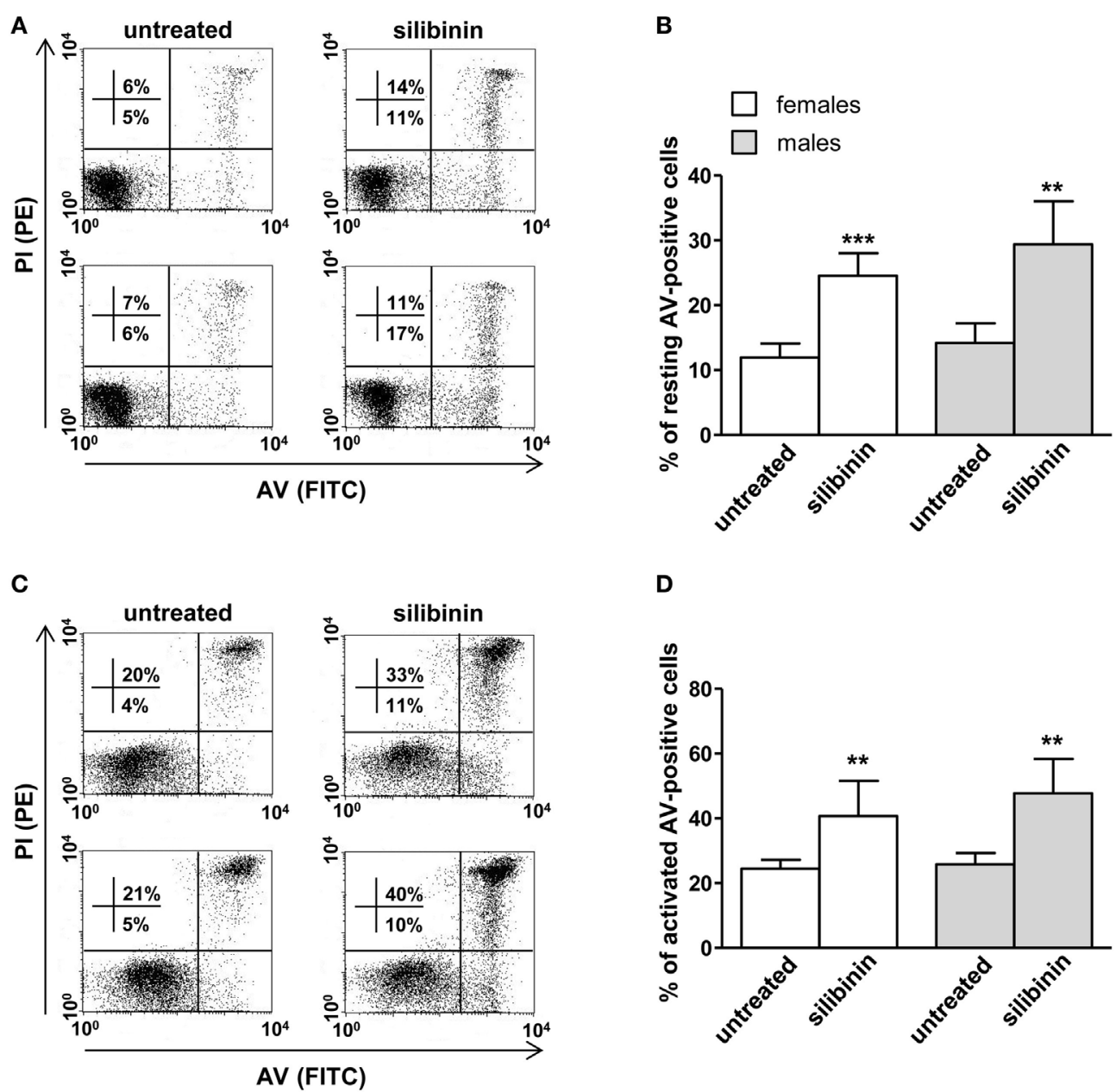

E

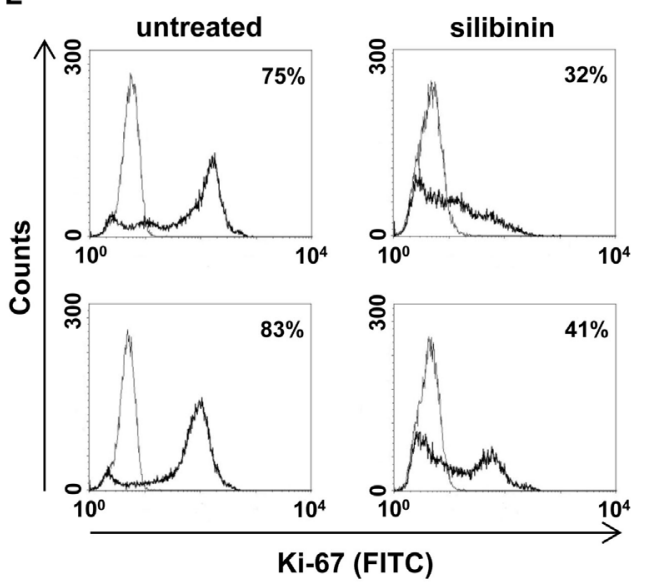

$\mathbf{F}$

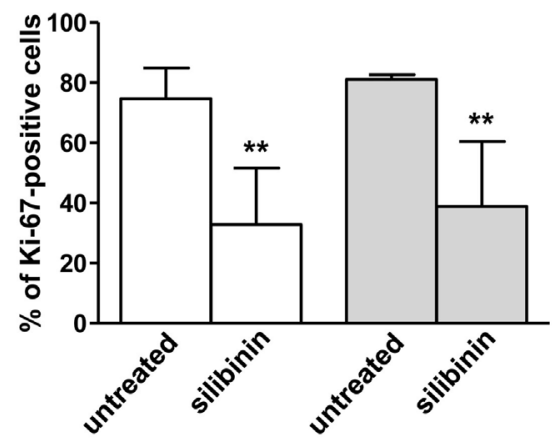

FIGURE 2 | Silibinin-dependent effects on apoptosis and proliferation levels of peripheral blood T lymphocytes from female and male healthy subjects. All experiments were performed in 23 female and 21 male healthy subjects. (A-D) Apoptosis assay involving dual staining with annexin $\mathrm{V}(\mathrm{AV})$ and propidium iodide (PI) was carried out using flow cytometry in resting $T$ cells treated or not with silibinin for $48 \mathrm{~h}(\mathbf{A}, \mathbf{B})$ and in T cells activated by anti-CD3 monoclonal antibody (mAb) for $72 \mathrm{~h}$ and treated or not with silibinin for the last $48 \mathrm{~h}$ of culture (C,D). Results from representative female (upper panels) and male (lower panels) healthy donors are shown $(\mathbf{A}, \mathbf{C})$. Numbers reported represent the percentages of AV positive/PI negative (early apoptotic, bottom right quadrant) and AV positive/PI positive (late apoptotic or necrotic cells, top right quadrant). Data referred to both $A \bigvee$ positive/PI negative and AV positive/PI positive cells are also reported as mean \pm SD (B,D). (E,F) Cell proliferation was evaluated by flow cytometry measuring Ki-67 nuclear antigen expression in T lymphocytes after activation with anti-CD3 mAb for $72 \mathrm{~h}$ and treatment with silibinin for the last $48 \mathrm{~h}$ of culture. Results from representative female (upper panels) and male (lower panels) healthy donors are shown (E). Data are also reported as mean $\pm \mathrm{SD}(\mathbf{F}) .{ }^{\star \star} P<0.01,{ }^{\star \star \star} P<0.001$ versus untreated cells. 

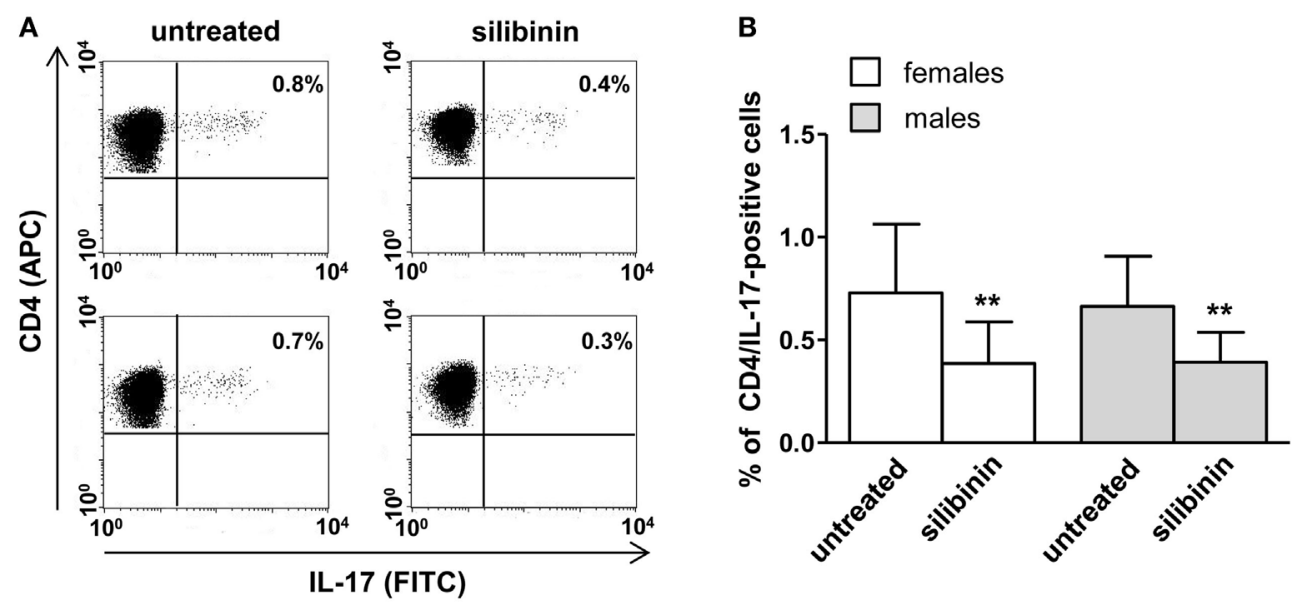

C

D
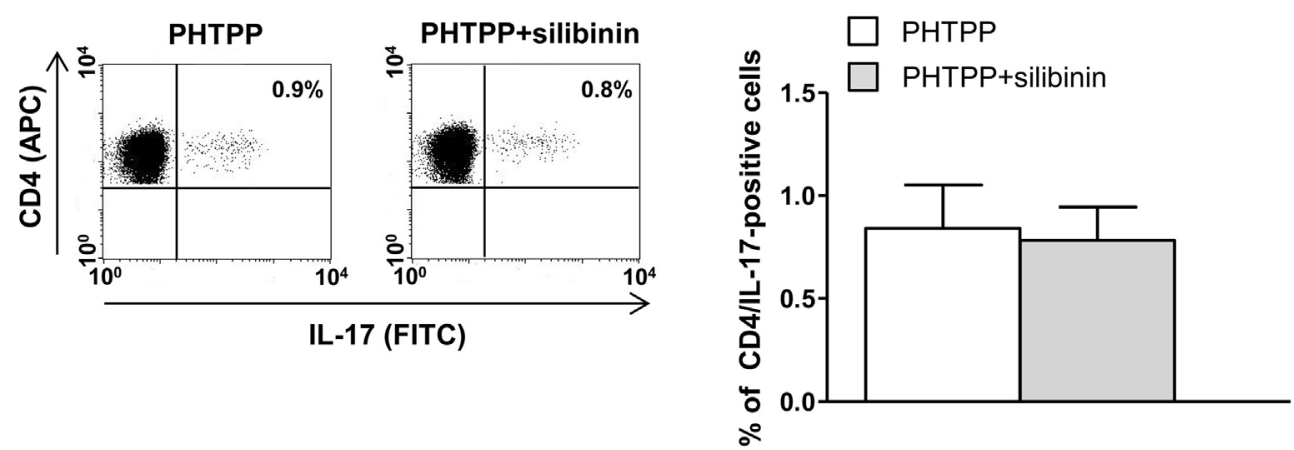

E

SSNC
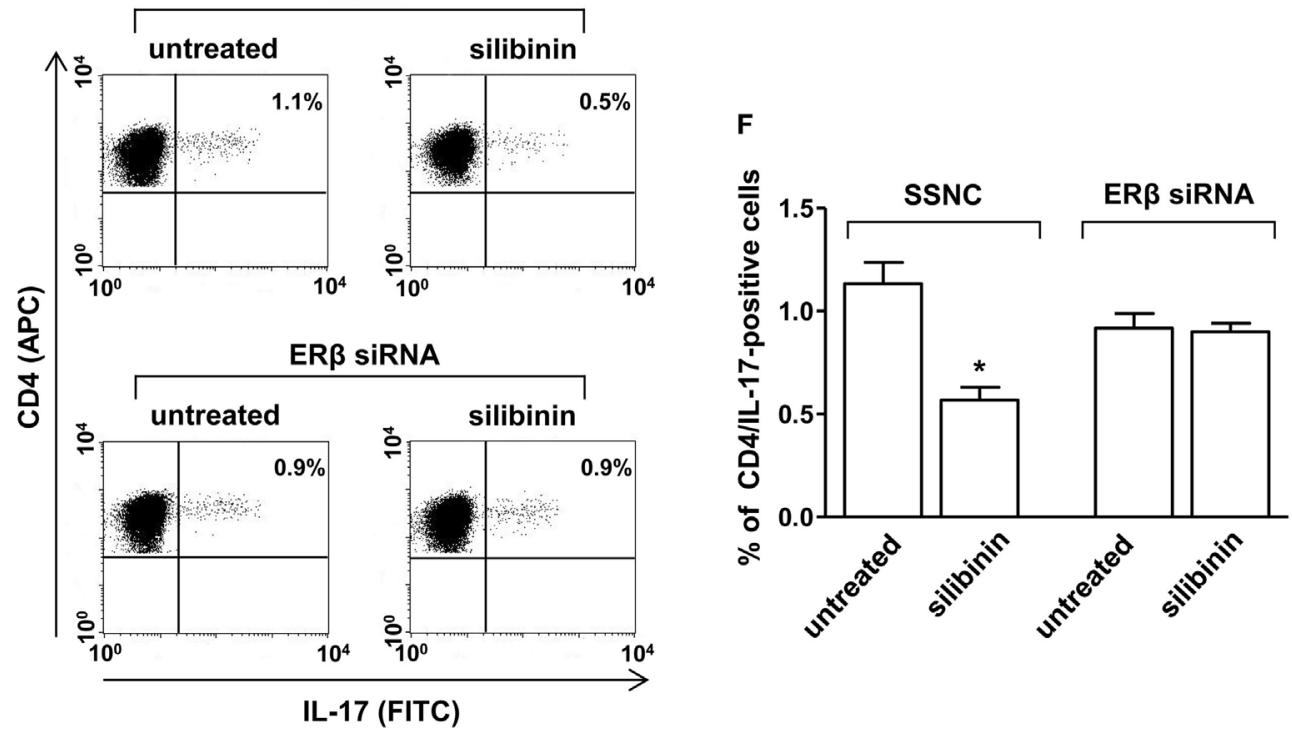

FIGURE 3 | Silibinin decreased IL-17 expression in peripheral blood T lymphocytes from female and male healthy subjects acting through estrogen receptor (ER) $\beta$ binding. (A,B) Cytokine expression was analyzed in 23 female and 21 male healthy subjects by flow cytometry after $48 \mathrm{~h}$ of culture with silibinin and stimulation with phorbol myristate acetate (PMA) and ionomycin in the presence of brefeldin for the last $4 \mathrm{~h}$ of culture as detailed in Section "Materials and Methods." Results from representative female (upper panels) and male (lower panels) healthy donors are shown (A). Data are also reported as mean \pm SD (B). (C,D) IL-17 expression was analyzed in T lymphocytes from three randomly selected female healthy donors pretreated with the ER $\beta$ antagonist PHTTP for $1 \mathrm{~h}$ before adding silibinin. Results from a representative female healthy donor are shown (C). Data are also reported as mean \pm SD (D). (E,F) IL-17 expression was analyzed in T lymphocytes from three randomly selected female healthy donors after silencing ER $\beta$ expression. Results from a representative female healthy donor are shown (E). Data are also reported as mean $\pm \mathrm{SD}$ (F). ${ }^{\star} P<0.05,{ }^{\star \star} P<0.01$ versus untreated cells. Abbreviation: SSNC, silencer select negative control siRNA. 
Dupuis et al.

Immunosuppressive Effects of Silibinin

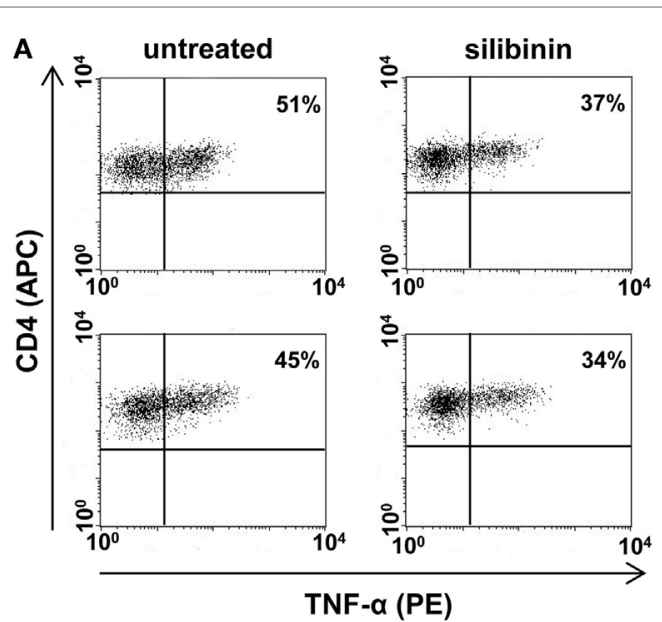

C

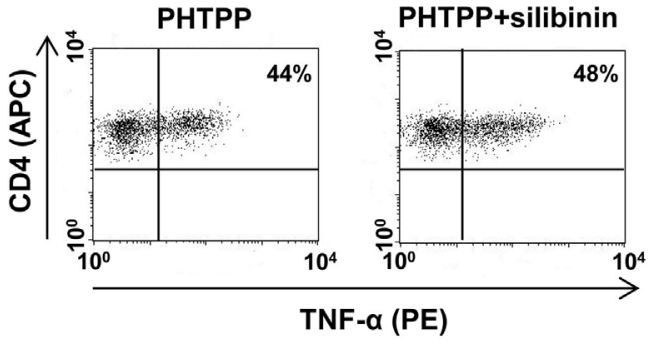

E

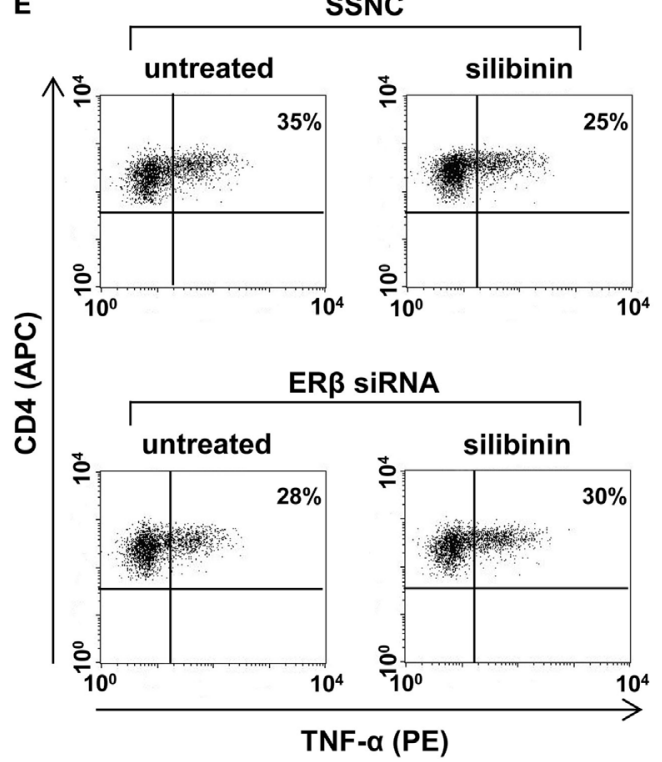

B

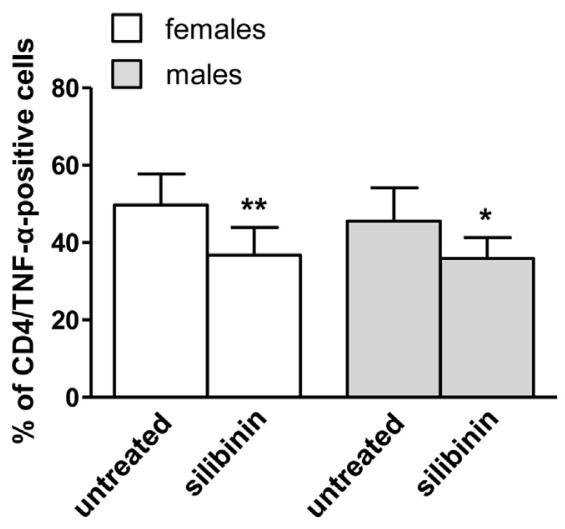

D
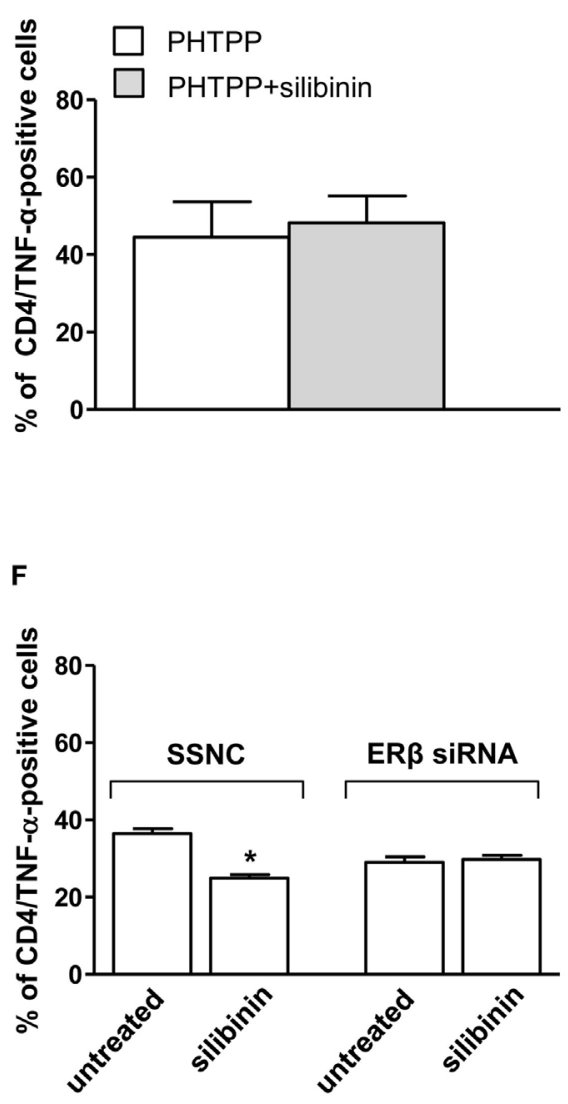

FIGURE 4 | Silibinin decreased TNF- $\alpha$ expression in peripheral blood CD4 ${ }^{+}$T lymphocytes from female and male healthy subjects acting through ER $\beta$ binding. (A,B) Cytokine expression were analyzed in 23 female and 21 male healthy subjects by flow cytometry after $48 \mathrm{~h}$ of culture with silibinin and stimulation with phorbol myristate acetate (PMA) and ionomycin in the presence of brefeldin for the last $16 \mathrm{~h}$ of culture as detailed in Section "Materials and Methods." Results from representative female (upper panels) and male (lower panels) healthy donors are shown (A). Data are also reported as mean \pm SD (B). (CD) TNF- $\alpha$ expression was analyzed in T lymphocytes from three randomly selected female healthy donors pretreated with the ER $\beta$ antagonist PHTTP for $1 \mathrm{~h}$ before adding silibinin. Results from a representative female healthy donor are shown (C). Data are also reported as mean \pm SD (D). (E,F) TNF- $\alpha$ expression was analyzed in T lymphocytes from three randomly selected female healthy donors after silencing ER $\beta$ expression. Results from a representative female healthy donor are shown (E). Data are also reported as mean $\pm \mathrm{SD}(\mathbf{F}) .{ }^{\star} P<0.05,{ }^{\star \star} P<0.01$ versus untreated cells. Abbreviation: SSNC, silencer select negative control siRNA.

Frontiers in Immunology | www.frontiersin.org

8

August 2018 | Volume 9 | Article 1903 
TABLE 2 | Cytokine expression at the single cell level by flow cytometry analysis of CD4 ${ }^{+}$and $\mathrm{CD}^{+} \mathrm{T}$ lymphocytes from female and male healthy donors.

\begin{tabular}{|c|c|c|c|c|c|c|}
\hline \multirow[t]{2}{*}{ Cytokines } & \multicolumn{3}{|c|}{ Females } & \multicolumn{3}{|c|}{ Males } \\
\hline & Untreated & Silibinin & $P$ & Untreated & Silibinin & $P$ \\
\hline$\% \mathrm{CD}^{+} / \mathrm{IL}-17^{+}$ & $0.7 \pm 0.3$ & $0.4 \pm 0.2$ & 0.0078 & $0.7 \pm 0.2$ & $0.4 \pm 0.1$ & 0.0077 \\
\hline$\% \mathrm{CD}^{+} / \mathrm{TNF}-\alpha^{+}$ & $50 \pm 8$ & $37 \pm 7$ & 0.0028 & $45 \pm 9$ & $36 \pm 5$ & 0.0272 \\
\hline$\% \mathrm{CD}^{+} / \mathrm{TNF}-\alpha^{+}$ & $30 \pm 12$ & $23 \pm 11$ & 0.1022 & $44 \pm 23$ & $36 \pm 26$ & 0.0943 \\
\hline$\% \mathrm{CD}^{+} / \mathrm{IL}^{-2} 2^{+}$ & $43 \pm 12$ & $39 \pm 12$ & 0.1141 & $49 \pm 10$ & $38 \pm 19$ & 0.0622 \\
\hline$\% \mathrm{CD}^{+} / \mathrm{IL}^{-2}{ }^{+}$ & $18 \pm 6$ & $16 \pm 9$ & 0.0562 & $23 \pm 6$ & $17 \pm 10$ & 0.0703 \\
\hline$\% \mathrm{CD}^{+} / \mathrm{IFN} \gamma^{+}$ & $30 \pm 11$ & $26 \pm 6$ & 0.4936 & $33 \pm 21$ & $42 \pm 22$ & 0.1236 \\
\hline$\% \mathrm{CD}^{+} / \mathrm{IFN} \gamma^{+}$ & $56 \pm 14$ & $48 \pm 18$ & 0.0937 & $65 \pm 33$ & $70 \pm 28$ & 0.7238 \\
\hline$\% \mathrm{CD}^{+} / \mathrm{IL}_{-4}^{+}$ & $0.3 \pm 0.2$ & $0.2 \pm 0.1$ & 0.0979 & $0.7 \pm 0.7$ & $1.4 \pm 1.5$ & 0.2364 \\
\hline$\%$ CD8+/IL-4+ & $0.3 \pm 0.2$ & $0.1 \pm 0.1$ & 0.0655 & $0.1 \pm 0.1$ & $0.1 \pm 0.1$ & 0.9892 \\
\hline$\% \mathrm{CD}^{+} / \mathrm{IL}-10^{+}$ & $1.1 \pm 0.6$ & $1.1 \pm 0.7$ & 0.9644 & $0.9 \pm 0.7$ & $1 \pm 1$ & 0.5081 \\
\hline
\end{tabular}

For $\mathrm{CD} 4^{+}$and $\mathrm{CD} 8^{+}$T lymphocyte subsets, data were expressed as the percentage of each subset within the $C D 3^{+} \mathrm{CD} 4^{+}$or $\mathrm{CD} 3^{+} \mathrm{CD} 8^{+}$population considered as $100 \%$. Data are represented as mean $\pm S D$ from 23 female and 21 male healthy subjects. $P$ values were calculated using the Mann-Whitney $U$ test.

role of ER $\beta$ in the anti-inflammatory effects induced by silibinin, we used two different approaches: (i) the pretreatment of PBMC with the ER $\beta$ antagonist PHTTP and (ii) the silencing of ER $\beta$ with specific siRNA to knockdown ER $\beta$ gene. Notably, in both experimental conditions, silibinin lost the ability to inhibit IL-17 (Figures 3C-F) and TNF- $\alpha$ expression (Figures 4C-F), confirming that the observed effects were mediated by ER $\beta$ binding.

Also in this set of experiments, no significant difference was observed between cells from male and female subjects after silibinin treatment (Figures 2-4).

To investigate whether the silibinin-mediated IL-17 inhibition could be due to elimination of memory Th17 cells or by a block of IL-17 production, we first evaluated intracellular ER $\beta$ expression in sorted Th17 cells (i.e., CD4 ${ }^{+} \mathrm{CD} 45 \mathrm{RA}^{-} \mathrm{CCR} 6^{+} \mathrm{CXCR} 3^{-}$, Figures S1A,B in Supplementary Material). As expected, the Th17 cell subset expressed intracellular ER $\beta$. Then, we evaluated apoptosis level of this cell subset, treated or not with silibinin (Figure S1C in Supplementary Material). An increase of apoptotic level after silibinin treatment was detected, suggesting that the effect of silibinin on IL-17 production was, at least partially, due to apoptosis induction in this cell subset. Also in this case, the ER $\beta$ antagonist PHTTP was able to inhibit silibin-induced apoptosis.

\section{Silibinin Effects on Peripheral Blood T Lymphocytes From Patients With Active RA}

Based on the results obtained in healthy donors, we decided to test the anti-inflammatory potential of silibinin on T lymphocytes from female and male patients with active RA, analyzing its ability to modulate apoptosis, proliferation, and cytokine expression. Similarly to that observed in healthy donors, silibinin induced a significant increase of apoptosis in T lymphocytes from RA patients in both resting $(P=0.0161$ for females and $P=0.0286$ for males, Figures 5A,B $)$ and activated state $(P=0.0403$ for females and $P=0.0421$ for males, Figures 5C,D). In addition, a significant reduction of proliferation level was detected after cell treatment with silibinin $(P=0.0160$ for females and $P=0.0286$ for males, Figures 5E,F). Notably, silibinin was able to significantly reduce IL-17 and TNF- $\alpha$ expression levels in $\mathrm{CD} 4^{+} \mathrm{T}$ lymphocytes (IL-17: $P=0.0235$ for females and $P=0.0294$ for males; TNF- $\alpha$ :
$P=0.0032$ for females and $P=0.0421$ for males, versus untreated cells, respectively, Figures 6A-D). Similarly to that observed in healthy subject, no significant difference was observed between cells from male and female subjects after silibinin treatment.

\section{Silibinin Effect on miR-155 Expression in Peripheral T Lymphocytes From Patients With Active RA}

Finally, we asked whether silibinin could act as an epigenetic modifier modulating miRNA expression. We focused on miR155 that plays a crucial role in the pathogenesis of RA (29-31) and which expression has been demonstrated to be modulated by estrogen through ER $\beta$ (38). Thus, we quantitatively analyzed miR-155 expression in T lymphocytes from RA patients, upon treatment with silibinin, by qRT-PCR assay. The results, shown in Figure 7, indicated an average 54 and 50\% (for females and males respectively) decreased expression of miR-155 in T lymphocytes after silibinin treatment, thus suggesting that this phytoestrogen acted as a downregulator of miR-155.

\section{DISCUSSION}

Our study provides new insights regarding the anti-inflammatory effects of the phytoestrogen silibinin in T cell immunity. First, we demonstrated that silibinin upregulates ER $\beta$ expression, induces apoptosis, inhibits proliferation, and reduces expression of the pro-inflammatory cytokines IL-17 and TNF- $\alpha$, through ER $\beta$ binding, in $\mathrm{T}$ lymphocytes from both female and male healthy subjects. Then, we confirmed these results in T lymphocytes from patients with RA in term of apoptosis, proliferation, and cytokine production. Finally, we found that silibinin acts as an epigenetic modifier, down-modulating the expression of miR-155 which plays a key role in the pathogenesis of RA.

Growing evidence suggests that ER $\alpha$ and $\mathrm{ER} \beta$ subtypes mediate distinct transcriptional activities when they are co-expressed in the same cells and that the quantity and distribution of these receptors are crucial for their biological effects (8). In particular, ER $\beta$ displays an anti-inflammatory effect and the upregulation of this receptor in immune cells may provide a useful tool in creating an anti-inflammatory milieu. Here, we observed for the 
A

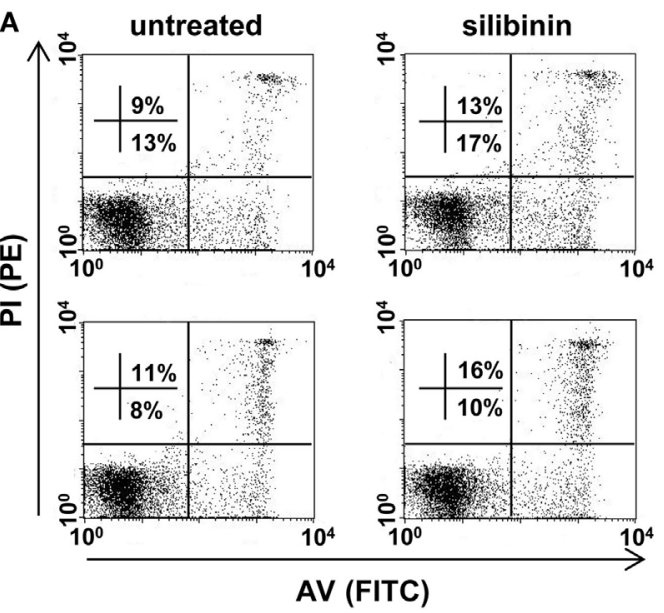

C

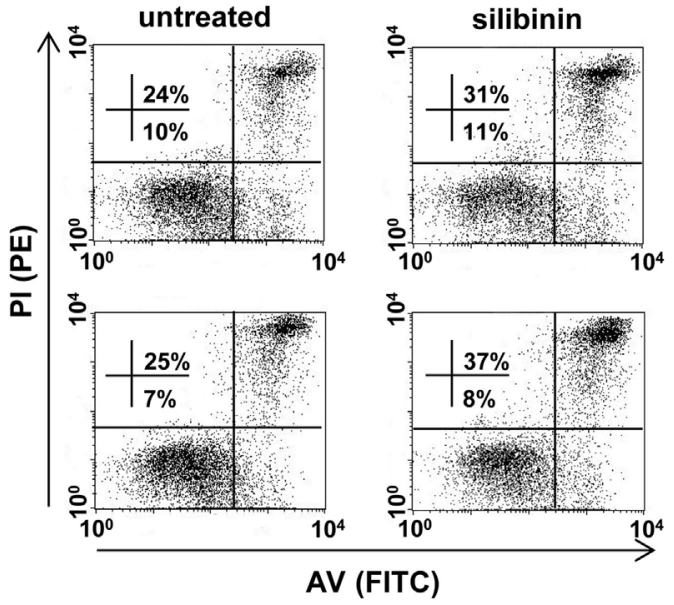

E

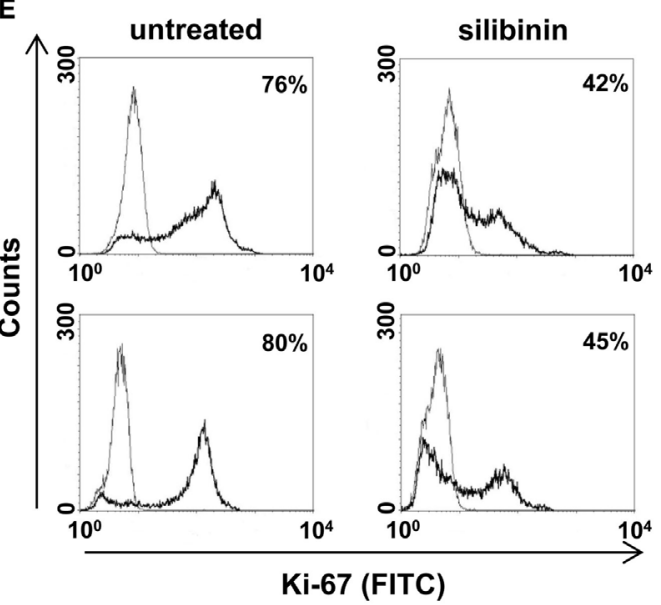

B

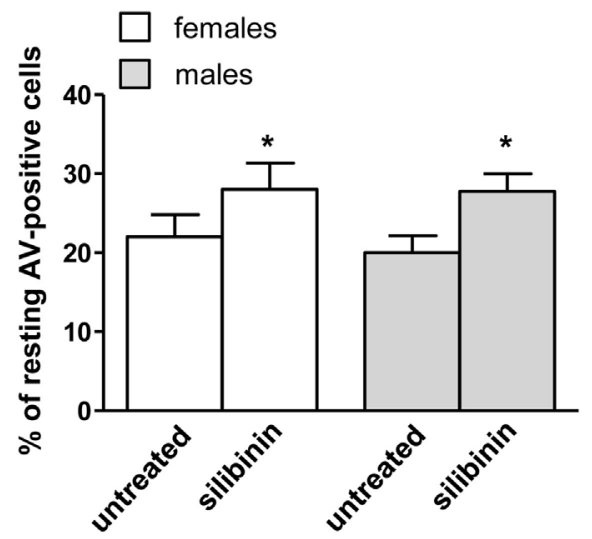

D

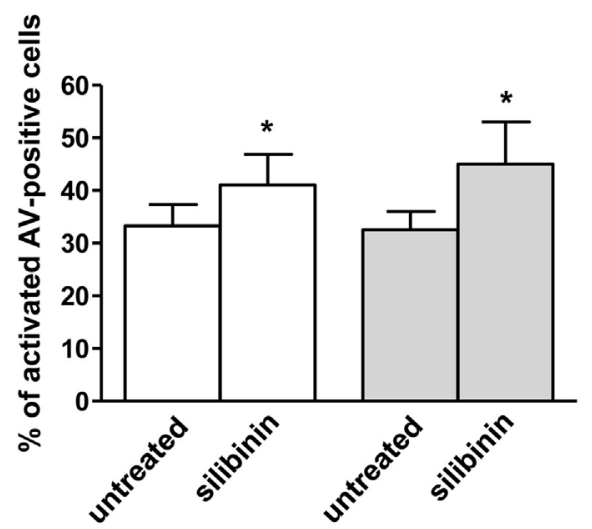

$\mathbf{F}$

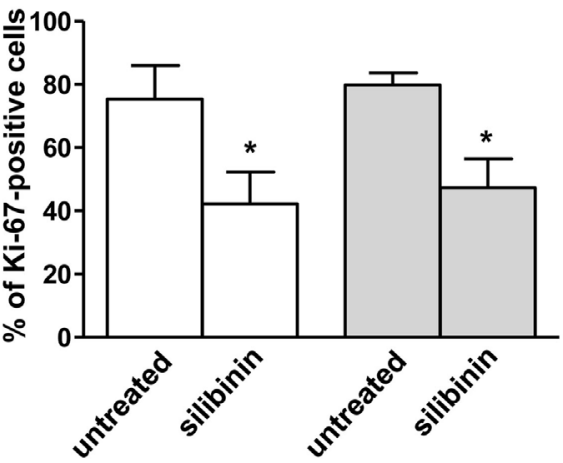

FIGURE 5 | Silibinin-dependent effects on apoptosis and proliferation levels of peripheral blood T lymphocytes from patients with active rheumatoid arthritis (RA). All experiments were performed in 10 female and 4 male RA patients. (A-D) Apoptosis assay involving dual staining with annexin $\mathrm{V}(\mathrm{AV})$ and propidium iodide (PI) was carried out using flow cytometry in resting T cells treated or not with silibinin for $48 \mathrm{~h}(\mathbf{A}, \mathbf{B})$ and in T cells activated by anti-CD3 monoclonal antibody $(\mathrm{mAb})$ for $72 \mathrm{~h}$ and treated or not with silibinin for the last $48 \mathrm{~h}$ of culture (C,D). Results from representative female (upper panels) and male (lower panels) RA patients are shown (A,C). Numbers reported represent the percentages of AV positive/PI negative (early apoptotic, bottom right quadrant) and AV positive/PI positive (late apoptotic or necrotic cells, top right quadrant). Data referred to both AV positive/PI negative and AV positive/PI positive cells are also reported as mean \pm SD (B,D). (E,F) Cell proliferation was evaluated by flow cytometry measuring Ki-67 nuclear antigen expression in T lymphocytes after activation with anti-CD3 mAb for $72 \mathrm{~h}$ and treatment with silibinin for the last $48 \mathrm{~h}$ of culture. Results from representative female (upper panels) and male (lower panels) RA patients are shown (E). Data are also reported as mean $\pm \mathrm{SD}(\mathbf{F}) .{ }^{*} P<0.05$ versus untreated cells. 

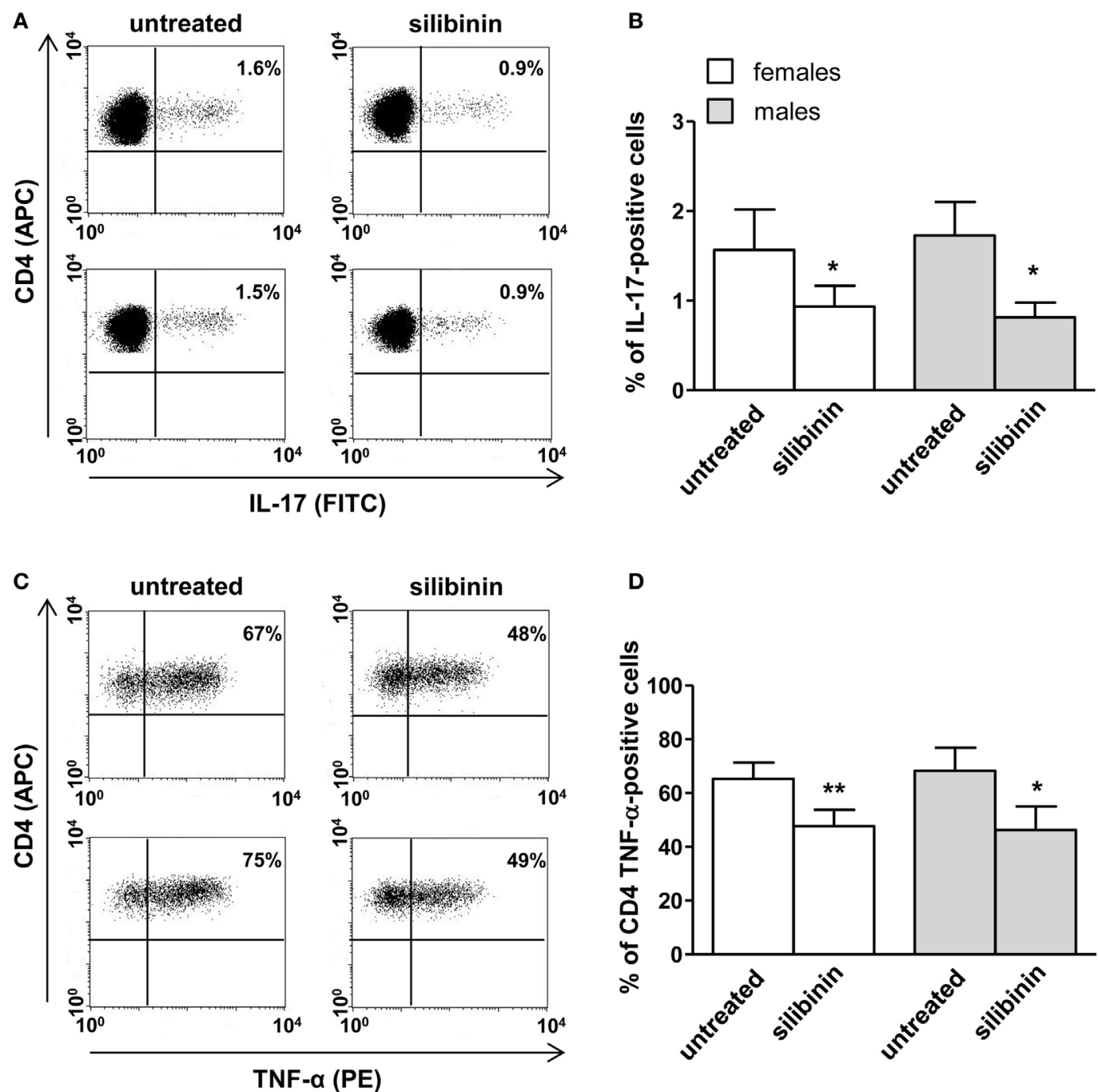

FIGURE 6 | Silibinin-dependent effects on IL-17 and TNF- $\alpha$ expression in peripheral blood T lymphocytes from rheumatoid arthritis (RA) patients. T lymphocytes from 10 female and 4 male RA patients were evaluated by flow cytometry for cytokine production after $48 \mathrm{~h}$ of culture with silibinin and stimulation with phorbol myristate acetate (PMA) and ionomycin in the presence of brefeldin as detailed in Section "Materials and Methods." Results from representative female (upper panels) and male (lower panels) RA patients are shown (A,C). Data are also reported as mean $\pm \mathrm{SD}$ (B, D). ${ }^{*} P<0.05,{ }^{\star \star} P<0.01$ versus untreated cells.

first time that silibinin was able to upregulate ER $\beta$ expression in T lymphocytes from both women and men.

Ligation of this receptor by silibinin induced an antiproliferative and a proapoptotic effect in T lymphocytes. These results are partially in accordance with those previously reported by other groups who observed that silymarin plays an antiproliferative activity (39-41) but, unlike what we have seen, it also has a proapoptotic effect $(39,40)$ in human T lymphocytes. The use by these authors of silymarin, which consists of a family of flavolignans including silybinin, isosilybinin, silychristin, isosilychristin, silydianin, and the flavonoid taxifoline, instead of the pure silibinin, might account for this discordant result. Interestingly, silibinin was able to strongly decrease the expression of the proinflammatory cytokines IL-17 and TNF- $\alpha$ through a mechanism that foresees its binding to $\mathrm{ER} \beta$, as demonstrated by the lack of silibinin effect when this receptor was knocked down. To note, all these experiments revealed that $\mathrm{T}$ lymphocytes from both sexes had the same susceptibility to silibinin. This is in line with previous observations that $\mathrm{T}$ lymphocytes from females and males subjects express similar basal levels of ER $\beta$ (12) and with our finding that silibinin upregulated $\operatorname{ER} \beta$ in both sexes, assigning to silibinin a role for the treatment of inflammatory diseases both in women and in men. To note that the selective activation of ER $\beta$ could be of clinical value since it does not induce the classic side effects, mediated by $\mathrm{ER} \alpha$, observed after estrogen administration (e.g., cerebro- and cardiovascular events, higher occurrence of endometrial and breast cancer).

Both IL-17 and TNF- $\alpha$ are known to play a critical role in the pathogenesis of RA as demonstrated by the success of treatments based on their inhibition by biological disease-modifying 
A

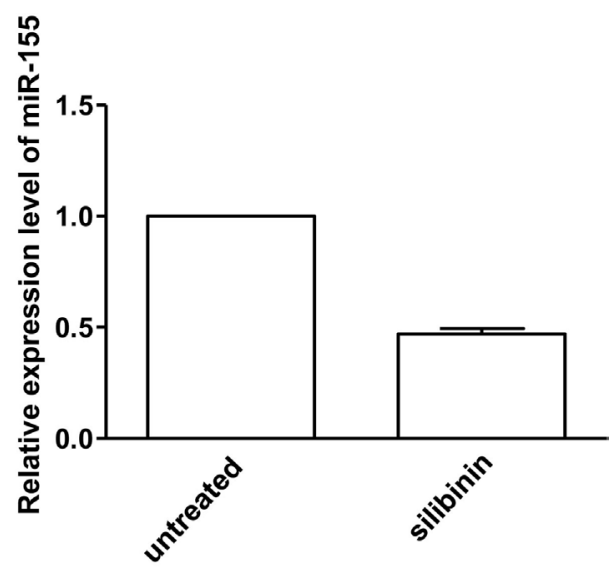

B

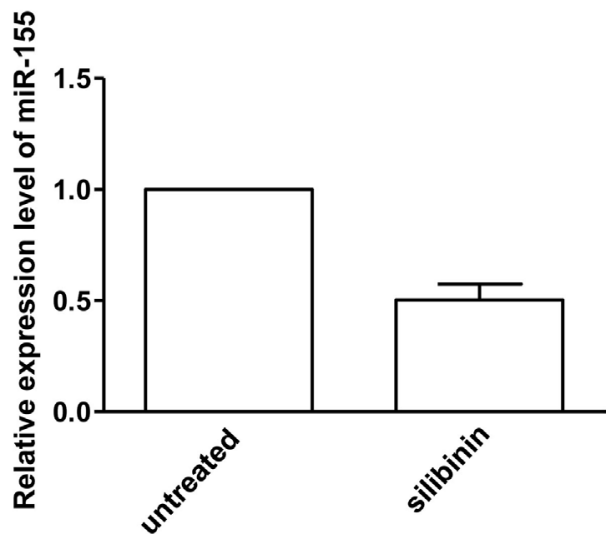

FIGURE 7 | Quantitative real-time PCR (qRT-PCR) analysis of microRNA-155 (miR-155) expression level in peripheral blood T lymphocytes from rheumatoid arthritis (RA) patients. qRT-PCR analysis of miR-155-3p expression level in T lymphocytes isolated from five female (A) and two male (B) RA patients, treated or not with silibinin for $48 \mathrm{~h}$. The values of fold change were calculated by the $2-\Delta \Delta \mathrm{Ct}$ method relative to untreated RA patient. The mean \pm SD values, referred to the fold of change between treated and untreated patients, were shown.

antirheumatic drugs $(42,43)$. Interleukin-17 and TNF- $\alpha$ modulate the migration of inflammatory cells into the joints and display additive or synergistic effects on human synovial fibroblasts (44). Accordingly, alterations in peripheral T lymphocyte homeostasis and unbalanced Th1 and Th17 cytokine profiles have been repeatedly demonstrated in RA patients (27). Thus, a drug able to block these two cytokines at the same time would be very useful for an effective therapeutic approach in inflammatory arthritis. Hence, with in mind the goal to propose silibinin as therapeutic tool in RA, we evaluated whether this phytoestrogen could exert its anti-inflammatory effects on $\mathrm{T}$ lymphocytes from patients with active RA who had a poor response to disease-modifying antirheumatic drugs. In agreement with the results obtained in healthy donors, silibinin appeared to have immunosuppressive/ anti-inflammatory effects on T lymphocytes from RA patients inducing apoptosis, inhibiting proliferation and both IL-17 and TNF- $\alpha$ expression, thus assigning to this molecule a potential value as therapeutic tool in this disease. In support of this assumption, a recent study by Tong et al. (45) showed that silibinin alleviated inflammation and induced apoptosis in human
RA fibroblast-like synoviocytes and had a beneficial effect on arthritis in rats.

Interestingly, Th1 and Th17 polarization have been recently associated with an overexpression of miR-155 whose deregulation plays a crucial role in the pathogenesis of RA contributing to the progress of inflammation $(29,30)$. miR-155 has been reported to be abnormally expressed in arthritis models and miR155-deficient mice do not develop collagen-induced arthritis and show significant reduced Th17 cells and autoantibody production (46). Furthermore, miR-155 expression in RA patients has been positively related to TNF- $\alpha, \mathrm{C}$-reactive protein, erythrocyte sedimentation rate levels, and DAS28 (47). Noteworthy, in this study, we observed a downregulation of miR-155 expression in T lymphocytes from RA patients treated with silibinin. Accordingly, He et al. (38) demonstrated that miR-155 is downregulated by estrogen through ER $\beta$, further supporting the crucial role of this receptor as potential therapeutic target in RA.

In conclusion, our in vitro study provided new insights regarding the anti-inflammatory activities of silibinin. However, in vivo assays (e.g., collagen-induced arthritis model) are needed to confirm the potential role of this compound as therapeutic tool in $\mathrm{RA}$, paving the way for clinical trials in this disease. In particular, the use of silibinin in combination with synthetic drugs might reduce their standard dosage and their related side effects. To note, clinical trials on silibinin effectiveness in the treatment of patients with hepatitis, cirrhosis, or biliary disorders demonstrated its safety with adverse events comparable to placebo $(24,48)$.

\section{ETHICS STATEMENT}

Investigation has been conducted in accordance with the ethical standards and with the Declaration of Helsinki, and according to national and international guidelines. It was approved by the institutional review board of Policlinico Umberto I (Rome, Italy). All enrolled subjects were provided with complete information about the study and asked to sign an informed consent.

\section{AUTHOR CONTRIBUTIONS}

MD, MG, AM, AR, SA, AF, and MTP designed and performed in vitro experiments and analyzed data. MS performed flow cytometry and cell sorting analysis. CA and FCe contributed to patient enrollment and sample collection. FCo, LG, and GV provided intellectual input throughout the study. MP and EO provided important contribution to the conception of the work as well as interpretation of data and manuscript writing. All the authors read and approved the final manuscript.

\section{FUNDING}

This work was partially supported by AIRC (IG16810 to EO) and Fondazione Peretti and Arcobaleno Onlus (to AM).

\section{SUPPLEMENTARY MATERIAL}

The Supplementary Material for this article can be found online at https:/www.frontiersin.org/articles/10.3389/fimmu.2018.01903/ full\#supplementary-material. 


\section{REFERENCES}

1. Cutolo M, Brizzolara R, Atzeni F, Capellino S, Straub RH, Puttini PC. The immunomodulatory effects of estrogens: clinical relevance in immune-mediated rheumatic diseases. Ann N Y Acad Sci (2010) 1193:36-42. doi:10.1111/j.1749-6632.2009.05383.x

2. Cunningham M, Gilkeson G. Estrogen receptors in immunity and autoimmunity. Clin Rev Allergy Immunol (2011) 40:66-73. doi:10.1007/ s12016-010-8203-5

3. Karpuzoglu E, Zouali M. The multi-faceted influences of estrogen on lymphocytes: toward novel immuno-interventions strategies for autoimmunity management. Clin Rev Allergy Immunol (2011) 40:16-26. doi:10.1007/ s12016-009-8188-0

4. Ortona E, Pierdominici M, Maselli A, Veroni C, Aloisi F, Shoenfeld Y. Sex-based differences in autoimmune diseases. Ann Ist Super Sanita (2016) 52:205-12. doi:10.4415/ANN_16_02_12

5. Bouman A, Heineman MJ, Faas MM. Sex hormones and the immune response in humans. Hum Reprod Update (2005) 11:411-23. doi:10.1093/humupd/ dmi008

6. Oertelt-Prigione S. The influence of sex and gender on the immune response. Autoimmun Rev (2012) 11:A479-85. doi:10.1016/j. autrev.2011.11.022

7. Pernis AB. Estrogen and CD4+ T cells. Curr Opin Rheumatol (2007) 19:414-20. doi:10.1097/BOR.0b013e328277ef2a

8. Straub RH. The complex role of estrogens in inflammation. Endocr Rev (2007) 28:521-74. doi:10.1210/er.2007-0001

9. Ngo ST, Steyn FJ, McCombe PA. Gender differences in autoimmune disease. Front Neuroendocrinol (2014) 35:347-69. doi:10.1016/j.yfrne.2014.04.004

10. Rider V, Foster RT, Evans M, Suenaga R, Abdou NI. Gender differences in autoimmune diseases: estrogen increases calcineurin expression in systemic lupus erythematosus. Clin Immunol Immunopathol (1998) 89:171-80. doi:10.1006/clin.1998.4604

11. Ascenzi P, Bocedi A, Marino M. Structure-function relationship of estrogen receptor alpha and beta: impact on human health. Mol Aspects Med (2006) 27:299-402. doi:10.1016/j.mam.2006.07.001

12. Phiel KL, Henderson RA, Adelman SJ, Elloso MM. Differential estrogen receptor gene expression in human peripheral blood mononuclear cell populations. Immunol Lett (2005) 97:107-13. doi:10.1016/j.imlet.2004. 10.007

13. Pierdominici M, Maselli A, Colasanti T, Giammarioli AM, Delunardo F, Vacirca D, et al. Estrogen receptor profiles in human peripheral blood lymphocytes. Immunol Lett (2010) 132:79-85. doi:10.1016/j.imlet.2010. 06.003

14. Rider V, Li X, Peterson G, Dawson J, Kimler BF, Abdou NI. Differential expression of estrogen receptors in women with systemic lupus erythematosus. J Rheumatol (2006) 33:1093-101.

15. Yakimchuk K, Jondal M, Okret S. Estrogen receptor alpha and beta in the normal immune system and in lymphoid malignancies. Mol Cell Endocrinol (2013) 375:121-9. doi:10.1016/j.mce.2013.05.016

16. Itoh N, Kim R, Peng M, DiFilippo E, Johnsonbaugh H, MacKenzie-Graham A, et al. Bedside to bench to bedside research: estrogen receptor beta ligand as a candidate neuroprotective treatment for multiple sclerosis. J Neuroimmunol (2017) 304:63-71. doi:10.1016/j.jneuroim.2016.09.017

17. Wisdom AJ, Cao Y, Itoh N, Spence RD, Voskuhl RR. Estrogen receptor-beta ligand treatment after disease onset is neuroprotective in the multiple sclerosis model. J Neurosci Res (2013) 91:901-8. doi:10.1002/jnr.23219

18. Tiwari-Woodruff S, Morales LB, Lee R, Voskuhl RR. Differential neuroprotective and antiinflammatory effects of estrogen receptor (ER)alpha and ERbeta ligand treatment. Proc Natl Acad Sci U S A (2007) 104:14813-8. doi:10.1073/ pnas.0703783104

19. Saijo K, Collier JG, Li AC, Katzenellenbogen JA, Glass CK. An ADIOLERbeta-CtBP transrepression pathway negatively regulates microglia-mediated inflammation. Cell (2011) 145:584-95. doi:10.1016/j.cell.2011. 03.050

20. Mohammad I, Starskaia I, Nagy T, Guo J, Yatkin E, Vaananen K, et al. Estrogen receptor alpha contributes to $\mathrm{T}$ cell-mediated autoimmune inflammation by promoting T cell activation and proliferation. Sci Signal (2018) 11:eaa9415. doi:10.1126/scisignal.aap9415
21. Maselli A, Conti F, Alessandri C, Colasanti T, Barbati C, Vomero M, et al. Low expression of estrogen receptor beta in $\mathrm{T}$ lymphocytes and high serum levels of anti-estrogen receptor alpha antibodies impact disease activity in female patients with systemic lupus erythematosus. Biol Sex Differ (2016) 7:3. doi:10.1186/s13293-016-0057-y

22. Pierdominici M, Maselli A, Varano B, Barbati C, Cesaro P, Spada C, et al. Linking estrogen receptor beta expression with inflammatory bowel disease activity. Oncotarget (2015) 6:40443-51. doi:10.18632/oncotarget.6217

23. Aggelakopoulou M, Kourepini E, Paschalidis N, Panoutsakopoulou V. ERbeta in CD4+ T cells is crucial for ligand-mediated suppression of central nervous system autoimmunity. J Immunol (2016) 196:4947-56. doi:10.4049/ jimmunol.1600246

24. Comelli MC, Mengs U, Schneider C, Prosdocimi M. Toward the definition of the mechanism of action of silymarin: activities related to cellular protection from toxic damage induced by chemotherapy. Integr Cancer Ther (2007) 6:120-9. doi:10.1177/1534735407302349

25. El-Shitany NA, Hegazy S, El-Desoky K. Evidences for antiosteoporotic and selective estrogen receptor modulator activity of silymarin compared with ethinylestradiol in ovariectomized rats. Phytomedicine (2010) 17:116-25. doi:10.1016/j.phymed.2009.05.012

26. Recalde G, Moreno-Sosa T, Yudica F, Quintero CA, Sanchez B, Jahn GA, et al. Contribution of sex steroids and prolactin to the modulation of $\mathrm{T}$ and $\mathrm{B}$ cells during autoimmunity. Autoimmun Rev (2018) 17(5):504-12. doi:10.1016/j. autrev.2018.03.006

27. Smolen JS, Aletaha D, McInnes IB. Rheumatoid arthritis. Lancet (2016) 388:2023-38. doi:10.1016/S0140-6736(16)30173-8

28. Podshivalova K, Salomon DR. MicroRNA regulation of T-lymphocyte immunity: modulation of molecular networks responsible for T-cell activation, differentiation, and development. Crit Rev Immunol (2013) 33:435-76. doi:10.1615/CritRevImmunol.2013006858

29. Su LC, Huang AF, Jia H, Liu Y, Xu WD. Role of microRNA-155 in rheumatoid arthritis. Int J Rheum Dis (2017) 20:1631-7. doi:10.1111/1756-185X.13202

30. Alivernini S, Gremese E, McSharry C, Tolusso B, Ferraccioli G, McInnes IB, et al. MicroRNA-155-at the critical interface of innate and adaptive immunity in arthritis. Front Immunol (2017) 8:1932. doi:10.3389/fimmu.2017.01932

31. Alivernini S, Kurowska-Stolarska M, Tolusso B, Benvenuto R, Elmesmari A, Canestri S, et al. MicroRNA-155 influences B-cell function through PU.1 in rheumatoid arthritis. Nat Commun (2016) 7:12970. doi:10.1038/ ncomms 12970

32. Aletaha D, Neogi T, Silman AJ, Funovits J, Felson DT, Bingham CO III, et al. 2010 Rheumatoid arthritis classification criteria: an American College of Rheumatology/European League Against Rheumatism Collaborative Initiative. Arthritis Rheum (2010) 62:2569-81. doi:10.1002/art.27584

33. Prevoo ML, van 't Hof MA, Kuper HH, van Leeuwen MA, van de Putte LB, van Riel PL. Modified disease activity scores that include twenty-eight-joint counts. Development and validation in a prospective longitudinal study of patients with rheumatoid arthritis. Arthritis Rheum (1995) 38:44-8. doi:10.1002/art.1780380107

34. Pierdominici M, Maselli A, Cecchetti S, Tinari A, Mastrofrancesco A, Alfe $\mathrm{M}$, et al. Diesel exhaust particle exposure in vitro impacts $\mathrm{T}$ lymphocyte phenotype and function. Part Fibre Toxicol (2014) 11:74. doi:10.1186/s12989014-0074-0

35. Fragale A, Romagnoli G, Licursi V, Buoncervello M, Del Vecchio G, Giuliani $\mathrm{C}$, et al. Antitumor effects of Epidrug/IFNalpha combination driven by modulated gene signatures in both colorectal cancer and dendritic cells. Cancer Immunol Res (2017) 5:604-16. doi:10.1158/2326-6066.CIR-17-0080

36. Cappelletti V, Miodini P, Di Fronzo G, Daidone MG. Modulation of estrogen receptor-beta isoforms by phytoestrogens in breast cancer cells. Int J Oncol (2006) 28:1185-91. doi:10.3892/ijo.28.5.1185

37. Zheng N, Liu L, Liu W, Zhang P, Huang H, Zang L, et al. ERbeta up-regulation was involved in silibinin-induced growth inhibition of human breast cancer MCF-7 cells. Arch Biochem Biophys (2016) 591:141-9. doi:10.1016/j. abb.2016.01.002

38. He YQ, Sheng JQ, Ling XL, Fu L, Jin P, Yen L, et al. Estradiol regulates miR-135b and mismatch repair gene expressions via estrogen receptor-beta in colorectal cells. Exp Mol Med (2012) 44:723-32. doi:10.3858/emm.2012.44.12.079

39. Gharagozloo M, Jafari S, Esmaeil N, Javid EN, Bagherpour B, Rezaei A. Immunosuppressive effect of silymarin on mitogen-activated protein kinase 
signalling pathway: the impact on T cell proliferation and cytokine production. Basic Clin Pharmacol Toxicol (2013) 113:209-14. doi:10.1111/bcpt.12088

40. Gharagozloo M, Javid EN, Rezaei A, Mousavizadeh K. Silymarin inhibits cell cycle progression and mTOR activity in activated human T cells: therapeutic implications for autoimmune diseases. Basic Clin Pharmacol Toxicol (2013) 112:251-6. doi:10.1111/bcpt.12032

41. Morishima C, Shuhart MC, Wang CC, Paschal DM, Apodaca MC, Liu Y, et al. Silymarin inhibits in vitro T-cell proliferation and cytokine production in hepatitis C virus infection. Gastroenterology (2010) 138:.e1-2. doi:10.1053/j. gastro.2009.09.021

42. Lubberts E. The IL-23-IL-17 axis in inflammatory arthritis. Nat Rev Rheumatol (2015) 11:415-29. doi:10.1038/nrrheum.2015.53

43. McInnes IB, Schett G. Cytokines in the pathogenesis of rheumatoid arthritis. Nat Rev Immunol (2007) 7:429-42. doi:10.1038/nri2094

44. Fischer JA, Hueber AJ, Wilson S, Galm M, Baum W, Kitson C, et al. Combined inhibition of tumor necrosis factor alpha and interleukin-17 as a therapeutic opportunity in rheumatoid arthritis: development and characterization of a novel bispecific antibody. Arthritis Rheumatol (2015) 67:51-62. doi:10.1002/ art.38896

45. Tong WW, Zhang C, Hong T, Liu DH, Wang C, Li J, et al. Silibinin alleviates inflammation and induces apoptosis in human rheumatoid arthritis fibroblast-like synoviocytes and has a therapeutic effect on arthritis in rats. Sci Rep (2018) 8:3241. doi:10.1038/s41598-018-21674-6
46. Bluml S, Bonelli M, Niederreiter B, Puchner A, Mayr G, Hayer S, et al. Essential role of microRNA-155 in the pathogenesis of autoimmune arthritis in mice. Arthritis Rheum (2011) 63:1281-8. doi:10.1002/art.30281

47. Long L, Yu P, Liu Y, Wang S, Li R, Shi J, et al. Upregulated microRNA-155 expression in peripheral blood mononuclear cells and fibroblast-like synoviocytes in rheumatoid arthritis. Clin Dev Immunol (2013) 2013:296139. doi:10.1155/2013/296139

48. Post-White J, Ladas EJ, Kelly KM. Advances in the use of milk thistle (Silybum marianum). Integr Cancer Ther (2007) 6:104-9. doi:10.1177/1534735407 301632

Conflict of Interest Statement: The research was conducted in the absence of any commercial or financial relationships that could be construed as a potential conflict of interest.

Copyright $\odot 2018$ Dupuis, Conti, Maselli, Pagano, Ruggieri, Anticoli, Fragale, Gabriele, Gagliardi, Sanchez, Ceccarelli, Alessandri, Valesini, Ortona and Pierdominici. This is an open-access article distributed under the terms of the Creative Commons Attribution License (CC BY). The use, distribution or reproduction in other forums is permitted, provided the original author(s) and the copyright owner(s) are credited and that the original publication in this journal is cited, in accordance with accepted academic practice. No use, distribution or reproduction is permitted which does not comply with these terms. 